through the implementation of research findings. The British research commitment amounts to $\$ 1,820,000$ or three percent of Forestry Commission expenditures, in personnel it amounts to some 15 percent of the graduate staff and 5 percent of the technical. Additional are the costs and staffing (comprising an additional 5 percent of the graduate and 5 percent of the technical staff) of the two Management Services Division sections, and of the forest related efforts of the other research agencies that would in the United States be undertaken by foresters.

As to the exportability of the organizational structures and policies, each country has its own special circumstances and the pattern of research that evolves must reflect national needs. Similarly in regard to the scale and orientation of the program. American research is of a high calibre and its extent impressive. It may be presumed to have developed to its present form in response to national require-

\section{The Physical and}

\section{Mechanical Properties of Whitebark Pine}

\section{By J. B. KASPER and T. SZABO}

Department of Fisheries \& Forestry

Canadian Forestry Service

Forest Research Laboratory

Calgary, Alberta

J. B. Kasper presently

Canadian Forestry Service

Forest Products Laboratory

Vancouver, B.C.

T. Szabo presently

Canadian Forestry Service

Forest Products Laboratory

Ottawa, Ontario

ODC 812.7

"Knowledge of the basic physical and mechanical properties of whiteback pine is needed to determine its potential use and proper classification in the lumber market."

\section{Abstract}

The results of physical and mechanical tests on samples from five whitebark pines (Pinus albicaulis Engelm.) clearly indicate that this species should be classed as soft pine.

Les propriétés physiques et mécaniques du Pin à blanche écorce (Pinus albicaulis Engelm.)

\section{Résumé}

Les résultats obtenus à la suite d'essais sur les propriétés physiques et mécaniques d'échantillons de cinq individus du pin à blanche écorce (Pinus albicaulis Engelm) montrent clairement que cette espèce forestière devrait être classée dans la catégorie des pins à bois mou.

\section{Introduction}

Paul (5) indicated that whitebark pine belongs to the soft pine group which includes western white pine (Pinus monticola Dougl.), eastern white pine (Pinus strobus L.) and sugar pine (Pinus lambertiana Dougl.), but he does not present physical evidence other than botanical classification and ments. Its methods of deployment of resources for research into the basic relationships and the close connections between the U.S.F.S. and University research are worthy of study in the development of a Canadian solution.

Nevertheless the British method of deployment of considerably lesser resources and the high return for the research dollar invested would seem to provide several indications for possible development of a problem-solving, developmental oriented Canadian forest resources research, that can make a major impact on practice through answering those questions that are of concern to the practitioner.

Thanks are due to Dr. F. C. Hummel, U.K. Forestry Commissioner and Mr. G. D. Holmes, Director of the Forestry Commission Research Division for materials and advice in the preparation of this paper. Responsibility for interpretation etc. rests with myself. visual observation to support his position. Because there is no basic information on the physical and mechanical properties available for whitebark pine, the lumber from this species is being marketed as lodgepole pine (3).

Knowledge of the basic physical and mechanical properties of whitebark pine is needed to determine its potential use and proper classification in the lumber market.

\section{Methods}

An area in the Crowsnest Forest, in southwestern Alberta, (Latitude $49^{\circ} 48^{\prime}$ and Longitude $114^{\circ} 35^{\prime}$ ) was selected for sampling whitebark pine (3). The five trees selected according to A.S.T.M. standard D-143-52 (1965) (1) averaged 16.1 inches in diameter outside bark, 73 feet in total height, 53 feet in merchantable height, 47.3 cubic feet in gross volume and 303 years of age.

One 8-foot butt log was taken from each of five whitebark pine trees selected to be used for mechanical-property tests. The samples were marked out on the logs according to A.S.T.M. Standard D143-52 (1965) (1). The logs were sawn into $2 \frac{1}{2}$ inch planks at a local sawmill. The planks were further reduced to obtain required dimensions for mechanical-property tests. The tests conducted were on static bending, compression parallel and perpendicular to the grain, and shear. 
Table 1. Comparison of physical and mechanical properties of whitebark and other species of pine grown in Canada ${ }^{1}$

\begin{tabular}{|c|c|c|c|c|c|}
\hline \multirow{2}{*}{ Properties } & \multicolumn{3}{|c|}{ Soft Pines } & \multicolumn{2}{|c|}{ Hard Pines } \\
\hline & $\begin{array}{c}\text { Whitebark } \\
\text { Pine }\end{array}$ & $\begin{array}{l}\text { Eastern White } \\
\text { Pine }^{2}\end{array}$ & $\begin{array}{l}\text { Western White } \\
\text { Pine }^{2}\end{array}$ & $\begin{array}{l}\text { Lodgepole } \\
\text { Pine }^{2}\end{array}$ & $\begin{array}{l}\text { Ponderosa } \\
\text { Pine }^{2}\end{array}$ \\
\hline $\begin{array}{l}\text { Place of growth of material tested....... } \\
\text { No. of locations sampled. } \ldots \ldots \ldots \ldots \ldots \ldots \\
\text { No. of trees tested..... } \\
\text { Specific gravity (oven-dry) } \\
\text { Specific gravity (basic) (volume green }\end{array}$ & $\begin{array}{r}\text { Alta. } \\
1 \\
5 \\
0.428\end{array}$ & $\begin{array}{c}\text { N.B., Que. Ont. } \\
4 \\
25 \\
0.384\end{array}$ & $\begin{array}{r}\text { B.C. } \\
3 \\
17 \\
0.398\end{array}$ & $\begin{array}{c}\text { B.C. Alta. } \\
2 \\
13 \\
0.455\end{array}$ & $\begin{array}{r}\text { B.C. } \\
3 \\
17 \\
0.489\end{array}$ \\
\hline 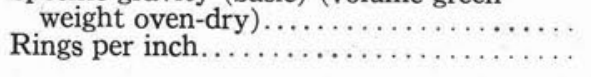 & $\begin{array}{r}0.369 \\
32\end{array}$ & $\begin{array}{r}0.364 \\
15\end{array}$ & $\begin{array}{r}0.355 \\
19\end{array}$ & $\begin{array}{r}0.403 \\
25\end{array}$ & $\begin{array}{r}0.438 \\
26\end{array}$ \\
\hline $\begin{array}{l}\text { Static Bending: } \\
\text { Stress at proportional limit (psi) ........ } \\
\text { Modulus of rupture (psi) } \ldots \ldots \ldots \ldots \\
\text { Modulus of elasticity }(1000 \mathrm{psi}) \ldots \ldots \ldots \\
\text { Work to proportional limit (in.lb./cu.in.) }\end{array}$ & $\begin{array}{l}3,295 \\
5,415 \\
1,056 \\
0.592\end{array}$ & $\begin{array}{l}3,000 \\
5,140 \\
1,180 \\
0.44\end{array}$ & $\begin{array}{l}2,890 \\
4,830 \\
1,190 \\
0.40\end{array}$ & $\begin{array}{l}2,970 \\
5,650 \\
1,270 \\
0.40\end{array}$ & $\begin{array}{l}3,320 \\
5,700 \\
1,130 \\
0.55\end{array}$ \\
\hline $\begin{array}{l}\text { Compression parallel to grain: } \\
\text { Stress at proportional limit }(\mathrm{psi}) \ldots \ldots \ldots \\
\text { Maximum crushing stress }(\mathrm{psi}) \ldots \ldots \ldots \ldots \\
\text { Modulus of elasticity }(1000 \mathrm{psi}) \ldots \ldots \ldots \ldots\end{array}$ & $\begin{array}{l}2,043 \\
2,318 \\
1,165\end{array}$ & $\begin{array}{l}1,950 \\
2,590 \\
1,260\end{array}$ & $\begin{array}{l}2,030 \\
2,520 \\
1,300\end{array}$ & $\begin{array}{l}2,220 \\
2,860 \\
1,420\end{array}$ & $\begin{array}{l}2,140 \\
2,840 \\
1,260\end{array}$ \\
\hline $\begin{array}{l}\text { Compression perpendicular to Grain: } \\
\text { Stress at proportional limit (psi) } \ldots \ldots \ldots\end{array}$ & 287 & 238 & 235 & 276 & 349 \\
\hline $\begin{array}{l}\text { Shear Parallel to Grain: } \\
\text { Maximum stress (psi)..... }\end{array}$ & 682 & 635 & 652 & 724 & 720 \\
\hline
\end{tabular}

${ }^{1}$ Averages for material tested in green condition.

${ }^{2}$ The properties of these species were obtained from Kennedy, E. I. 1965.

Strength and Related Properties of Woods Grown in Canada. Dept. of Forestry Publication No. 1104.

Preparation of each test specimen and performance of each test followed specifications given by A.S.T.M. designation D-143-52 (1965) (1). Since whitebark pine is not a major tree species in Alberta or elsewhere in Canada, the mechanical property loads were determined only for specimens in green condition.

Disks six inches thick were taken from each tree at stump height and then at intervals of 8 feet for determination of specific gravity and percent summerwood. The north side was marked and an average radius was determined for each disk. The average radius closest to north was also marked and a sample strip was cut along this radius.

The cross-sectional face of the strip was smoothed, with a microtome knife, for measurement of ring width and determination of percent summerwood. Ring width was measured to 0.001 inch with a tree-ring measuring instrument (4). The strips were then cut into samples representing 10 year increments from the bark to the pith. These samples were used for determination of specific gravity by the green-volume-oven-dry-weight method (2).

\section{Results and Discussion}

Results of the mechanical tests are presented in Table 1. The measured properties of the whitebark pines agree closely with those of other species in the white pines or soft pines classification but compared with the hard pines, whitebark pine is generally weaker.

Table 1 shows whitebark pine to have a slightly higher average specific gravity than the two soft pines; but whitebark has a considerably lower average specific gravity than the hard pines.

Results of the tests on physical properties of the samples from whitebark pine are given in Table 2.
Table 2. Physical properties of whitebark pine*

\begin{tabular}{lcccc}
\multicolumn{1}{c}{ Properties } & Mean & Minimum Maximum the Mean \\
\hline $\begin{array}{c}\text { Specific gravity } \\
\text { (basic) }\end{array}$ & 0.369 & 0.186 & 0.529 & 0.0015 \\
$\begin{array}{c}\text { Ave. ringwidth } \\
\text { (inches) }\end{array}$ & 0.023 & 0.002 & 0.081 & 0.00054 \\
$\begin{array}{c}\text { Ave. percent sum- } \\
\text { merwood per } \\
\text { ring }\end{array}$ & 8.53 & 2.27 & 30.25 & 0.148 \\
\hline
\end{tabular}

*Based on 740 observations.

The patterns observed in the data were: (a) specific gravity decreased with tree height, (b) specific gravity decreased with the age from the pith and (c) percent summerwood decreased as ring width increased.

The evidence collected from five trees indicates clearly that whitebark pine should be classified with other soft pine lumber.

\section{Acknowledgements}

Acknowledgements are due the Timber Engineering Section of the Vancouver Forest Products Laboratory for their interest and assistance in this study and for the use of their facilities. The loan of the tree-ring measuring instrument by $\mathrm{Dr}$. J. P. Howe, College of Forestry, Wildlife and Range Scences, University of Idaho is also gratefully acknowledged.

\section{Literature Cited}

(1) AMERICAN SOCIETY FOR TESTING AND MATERIALS 1967. Testing small clear specimens of timber (D-143. 52). Book A.S.T.M. Stand. Part 16: 69-129.

(2) BROWNING, B. S. 1967. Methods of wood chemistry Vol. I Intersci. Publ. N. Y. 384 p.

(3) DAY, R. J. 1967. Whitebark pine in the Rocky Mountains of Alberta. Forest. Chron. 43(3): 278-284. tains of Alberta. Forest. Chron. 43(3): 278-284.

(4) HOWE, J. P. 1961. Factors affecting the quality of inland Douglas-fir - a preliminary report. Forest Wildlife and Range Exp. Sta. Univ. Idaho. Res. Note No. 1710 p.

(5) PAUL, B. H. 1962. Properties and uses of western pines. Woodworking Dig. 64(1): 43-45. 